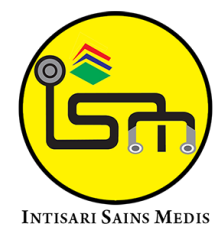

Published by Intisari Sains Medis

\section{Hubungan antara ekspresi Vascular Cell Adhesion Molecule-1 (VCAM-1) dengan tipe dan stadium T karsinoma epitel permukaan ovarium di RSUP Sanglah, Bali, Indonesia}

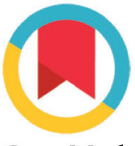

CrossMark

I Made Wirya Sastra ${ }^{1 *}$, Luh Putu lin Indrayani Maker ${ }^{1}$, Anak Agung Ayu Ngurah Susraini', I Wayan Juli Sumadi', I Gusti Ayu Sri Mahendra Dewi', Herman Saputra', I Made Muliarta²

'Departemen Patologi Anatomi, Fakultas Kedokteran, Universitas Udayana, RSUP Sanglah, Bali, Indonesia;

${ }^{2}$ Departemen Fisiologi, Fakultas Kedokteran, Universitas Udayana, Bali, Indonesia;

*Korespondensi:

I Made Wirya Sastra;

Departemen Patologi Anatomi, Fakultas Kedokteran, Universitas Udayana, RSUP Sanglah, Bali, Indonesia; madewirya97@gmail.com

Diterima: 08-04-2021

Disetujui: 26-07-2021

Diterbitkan: 10-08-2021

\section{ABSTRACT}

Background: Vascular Cell Adhesion Molecule-1 (VCAM-1) is an important protein in oncogenesis, angiogenesis, tumor development, and metastasis. Studies regarding the expression of VCAM-1 in ovarian carcinoma have found both supportive and contradictory results. Therefore, this study evaluates the relationship between VCAM-1 expression and the type and stage of ovarian surface epithelial carcinoma at Sanglah General Hospital, Bali, Indonesia.

Methods: This study was a cross-sectional analytical study with a sample size of 36 , which came from paraffin block of patients with ovarian surface epithelial carcinoma who were examined histopathologically at the Anatomical Pathology Laboratory of Sanglah Hospital Denpasar from 1 January 2017 to 31 December 2019. Samples are grouped into type I and type II, then the stage I or II and III groups. After that, the VCAM-1 immunohistochemical streak was performed to assess

high or low expression in these groups and analyzed its relationship with the type and stage $T$ of ovarian surface epithelial carcinoma. Data were analyzed using SPSS version 25 for Windows.

Results: The analysis results using the Chi-Square test showed a statistically significant relationship $(p=0.001)$ between the VCAM- 1 expression with type and stage surface epithelial ovarian carcinoma $(p=0.007)$. The results of the mean difference test are $0.48(95 \% \mathrm{Cl}=0.33-0.70)$ and showed a statistically significant difference $(p=0.001)$ between VCAM-1 expression with a type of ovarian carcinoma.

Conclusion: In conclusion, there is an association between expression VCAM-1 with the type of surface epithelial ovarian carcinoma and at a stage, with a 2.3 times higher probability of VCAM-1 expression in the stage III group than in stage I or II group.

Keywords: Ovarian Carcinoma, VCAM-1, Stage T.

Cite This Article: Sastra, I.M.W., Maker, L.P.I.I., Susraini, A.A.A.N., Sumadi, I.W.J., Dewi, I.G.A.S.M., Saputra, H., Muliarta, I.M. 2021. Hubungan antara ekspresi Vascular Cell Adhesion Molecule-1 (VCAM-1) dengan tipe dan stadium T karsinoma epitel permukaan ovarium di RSUP Sanglah, Bali, Indonesia. Intisari Sains Medis 12(2): 551556. Dol: $10.15562 /$ ism.v12i2.1023

\title{
ABSTRAK
}

Latar Belakang: Vascular Cell Adhesion Molecule-1 (VCAM-1) merupakan salah satu protein yang penting dalam onkogenesis, angiogenesis, perkembangan tumor dan metastasis. Penelitian-penelitian mengenai ekspresi VCAM-1 pada karsinoma ovarium mendapatkan hasil yang pro dan kontra. Oleh karena itu, penelitian ini bertujuan untuk mengetahui hubungan antara ekspresi VCAM-1 dengan tipe dan stadium $\mathrm{T}$ karsinoma epitel permukaan ovarium di RSUP Sanglah, Bali, Indonesia.

Metode: Penelitian ini merupakan studi analitik potong lintang dengan besar sampel adalah 36 , yang berasal dari dari blok parafin penderita karsinoma epitel permukaan ovarium yang diperiksa secara histopatologi di Laboratorium Patologi Anatomi RSUP Sanglah Denpasar dari 1 Januari 2017 sampai 31 Desember 2019. Sampel dikelompokkan menjadi tipe I dan tipe II, kemudian kelompok stadium I atau || dan III. Setelah itu dilakukan pulasan imunohistokimia VCAM-1 untuk menilai ekspresi tinggi ataupun rendah pada kelompok-kelompok tersebut dan dianalisis hubungannya dengan tipe dan stadium T karsinoma epitel permukaan ovarium. Data dianalisis dengan uji Chi-Square dengan nilai $p<0,05$.

Hasil: Hasil penelitian menunjukkan terdapat hubungan yang bermakna secara statistik $(p=0,001)$ 
antara ekpresi VCAM-1 dengan tipe karsinoma dan stadium T ( $p=0,007)$. Hasil uji beda rerata adalah 0,48 (IK 95\%=0,33-0,70) dan menunjukkan perbedaan bermakna secara statistik $(p=0,001)$ antara ekspresi VCAM-1 dengan tipe karsinoma ovarium.

Kesimpulan: Sebagai simpulan, terdapat hubungan antara ekspresi VCAM-1 dengan tipe karsinoma epitel permukaan ovarium dan pada stadium, dengan kemungkinan 2,3 kali terjadi ekspresi VCAM-1 yang tinggi pada kelompok stadium III dibandingkan stadium I atau II.

Kata kunci: Karsinoma Ovarium, VCAM-1, Stadium T.

Sitasi Artikel ini: Sastra, I.M.W., Maker, L.P.I.I., Susraini, A.A.A.N., Sumadi, I.W.J., Dewi, I.G.A.S.M., Saputra, H., Muliarta, I.M. 2021. Hubungan antara ekspresi Vascular Cell Adhesion Molecule-1 (VCAM-1) dengan tipe dan stadium T karsinoma epitel permukaan ovarium di RSUP Sanglah, Bali, Indonesia. Intisari Sains Medis 12(2): $551-$ 556. D0I: 10.15562/ism.v12i2.1023

\section{PENDAHULUAN}

Karsinoma ovarium merupakan satu dari keganasan ginekologi yang paling sering ditemukan pada stadium lanjut dan penyebab kematian kelima pada wanita dengan karakteristik penyebaran luas ke peritoneal dan ditemukan pada cairan asites. ${ }^{1,2}$ Penelitian epidemiologi kanker ovarium sangat bervariasi tergantung pada masing-masing klasifikasinya. ${ }^{3}$ Kanker ovarium di RSUP Sanglah pada periode ini terbanyak terjadi pada rentang usia 41 - 50 tahun $(38,4 \%)$, pada stadium IIIC (50,7\%) dengan tipe histopatologi epitel permukaan $(87,67 \%)$ subtipe serosa $(24,66 \%)$, serta paritas $\leq$ dua $(79,44 \%){ }^{4}$

Beberapa faktor-faktor risiko penting yang diketahui menyebabkan terjadinya kanker ovarium adalah nulipara, mutasi germline pada tumor supresor gen tertentu. ${ }^{5}$ Suatu penelitian menyebutkan bahwa karsinoma epitel permukaan ovarium paling sering yaitu karsinoma serus derajat tinggi $(70 \%$ dari seluruh karsinoma ovarium), karsinoma serus derajat rendah (kurang dari 5\%), karsinoma musinus (3-4\% dari seluruh karsinoma ovarium), dan karsinoma endometrioid (10\% dari seluruh karsinoma ovarium). ${ }^{6}$ Penelitian lain menyebutkan bahwa faktor-faktor prognostik karsinoma ovarium ditentukan berdasarkan tipe histologi, stadium International Federation of Gynecology and Obstetrics (FIGO) dan grade tumor. ${ }^{3}$ Hasil studi yang dilakukan oleh Hsieh SF et al., juga menunjukkan adanya hubungan yg bermakna terhadap faktor-faktor prognostik (tipe histologi, stadium FIGO dan grade tumor) pada kelangsungan hidup bebas atau Disease Free Survival (DFS) 5 tahun dan untuk faktor prognostik seperti usia dalam rentang $\leq 50$ tahun dan $>50$ tahun tidak menunjukkan hubungan yang bermakna. ${ }^{7}$

Vascular Cell Adhesion Molecule-1 (VCAM-1) mempunyai peran penting dalam onkogenesis, tumor angiogenesis, perkembangan tumor, dan metastasis kanker pada manusia. ${ }^{8}$ VCAM-1 bisa menstimulasi sel-sel kanker ovarium bergerak menuju kavum peritoneal karena perannya sebagai reseptor yang ditemukan di permukaan sel endothelial dan mesothelial. VCAM-1 menunjukkan nilai sensitivitas $86,0 \%$ terdeteksi di kanker ovarium stadium awal dan menunjukkan nilai sensitivitas $93,0 \%$ dan spesifisitas $98,0 \%$ pada kanker ovarium stadium lanjut. ${ }^{9}$ Karena peranan VCAM1 berperan penting pada pertumbuhan tumor ovarium dan kemungkinan dengan menghambat ikatan dengan integrin $\alpha 4 \beta 1$ dapat digunakan sebagai faktor prognostik dan terapi target potensial. ${ }^{10}$ Scalici JM et al., menemukan adanya hubungan yang bermakna secara statistik antara ekspresi VCAM-1 dengan stadium karsinoma ovarium, namun hasil yang ditunjukkan oleh Huang $J$ et al., menyebutkan tidak terdapat hubungan yang bermakna secara statistik dengan penilaian stadium. ${ }^{10,11}$

Berdasarkan pemaparan di atas, maka penelitian ini berupaya untuk mengetahui hubungan antara ekspresi VCAM-1 dengan tipe dan stadium $\mathrm{T}$ karsinoma epitel permukaan ovarium di RSUP Sanglah, Bali, Indonesia.

\section{METODE}

Penelitian ini menggunakan rancangan studi analitik potong lintang untuk mengetahui hubungan ekspresi VCAM-1 dengan tipe karsinoma epitel permukaan ovarium (Tipe I dan Tipe II) dan stadium T (I atau II, dan III) di RSUP Sanglah Denpasar.

Kriteria inklusi sampel penelitian adalah penderita karsinoma epitel permukaan ovarium yang blok parafinnya diperiksa secara histopatologi di Laboratorium Patologi Anatomi Fakultas Kedokteran Universitas Udayana/RSUP Sanglah Denpasar dari 1 Januari 2017 sampai 31 Desember 2019. Teknik Total Sampling dilakukan pada penelitian ini dimana didapatkan sebanyak 36 sampel penelitian.

Karsinoma epitel permukaan ovarium dikelompokan berdasarkan karsinogenesis dan patologi molekuler yaitu kelompok karsinoma epitel permukaan ovarium tipe I dan karsinoma epitel permukaan ovarium tipe II. $^{3}$ Stadium $\mathrm{T}$ pada karsinoma epitel permukaan ovarium dikelompokkan menjadi stadium I atau II dan stadium III. Stadium I yaitu tumor terbatas pada ovarium dan stadium II yaitu tumor melibatkan satu atau kedua ovarium atau tuba falopi dengan perluasan pelvis di bawah tepi pelvis atau karsinoma peritoneal primer. Stadium III yaitu tumor melibatkan satu atau kedua ovarium atau tuba falopi atau karsinoma peritoneal primer, dengan sitologi maupun histologi yang sudah mengkonfirmasi penyebaran keluar peritoneum pelvis Pengelompokan stadium I atau II berdasarkan tindakan pembedahan secara 
umum dan stadium III yang memerlukan debulking atau pembedahan cytoreductive yang mempengaruhi prognostik dan kelangsungan hidup pasien pada karsinoma epitel permukaan ovarium. ${ }^{3}$

Interpretasi ekspresi VCAM-1 dilakukan secara blind oleh peneliti dan 2 orang ahli Patologi Anatomi dan independen tanpa mengetahui data klinikopatologi pasien. Bila terjadi perbedaan pendapat tentang interpretasi ekspresi VCAM-1 dilakukan kesepakatan bersamasecarakonsensus. Pulasan VCAM1 Monoclonal Antibody dievaluasi pada sitoplasma sel karsinoma menggunakan mikroskop cahaya binokuler Olympus CX31 LED. Pulasan VCAM-1 dikatakan ekspresi tinggi jika VCAM-1 terpulas pada $\geq 30 \%$ sitoplasma sel karsinoma ovarium tanpa menilai intensitasnya dan ekspresi rendah bila terpulas $<30 \%$ pada sitoplasma sel karsinoma ovarium tanpa melihat intensitasnya. ${ }^{10}$

Data diolah dengan menggunakan program Statistical Package for the Social Sciences (SPSS) versi 25 untuk Windows. Analisis deskriptif meliputi karakteristik sampel. Analisis Chi square menganalisis hubungan antara ekspresi VCAM-1 dan derajat karsinoma ovarium tipe I dan tipe II, dan stadium T. Nilai batas kemaknaan (a) ditentukan pada tingkat kemaknaan $\mathrm{p}$ $<0,05$.

\section{HASIL}

Tabel 1 menunjukkan jumlah kasus berdasarkan beberapa parameter klinikopatologis. Distribusi kasus berdasarkan kelompok usia yaitu dekade ketiga terdapat 3 pasien $(8,3 \%)$, dekade keempat terdapat 4 pasien $(11,1 \%)$, dekade kelima terdapat 13 pasien $(36,1 \%)$, dekade keenam didapatkan sebanyak 14 pasien $(38,9 \%)$ dan dekade ketujuh didapatkan 7 pasien (5,6\%) (Tabel 1).

Berdasarkan parameter tipe karsinoma epitel permukaan ovarium, jumlah kasus karsinoma epitel permukaan ovarium tipe I sebanyak 20 pasien $(55,6 \%)$ terdiri dari 3 pasien $(8,3 \%)$ Clear cell carcinoma, 2 pasien $(5,6 \%)$ endometrioid carcinoma grade 1,3 pasien $(8,3 \%)$ endometrioid carcinoma grade 2, 6 pasien $(13,9 \%)$ Low Grade Serous Carcinoma, 1 pasien $(2,8 \%)$ malignant brenner tumor, 4 pasien $(11,1 \%)$ mucinous carcinoma, 1 pasien

\section{Tabel 1. Jumlah kasus pada beberapa parameter klinikopatologis}

\begin{tabular}{|c|c|}
\hline Parameter & Total $(\mathrm{N}=36)$ \\
\hline \multicolumn{2}{|l|}{ Usia (Tahun), n (\%) } \\
\hline Dekade 3 & $3(8,3)$ \\
\hline Dekade 4 & $4(11,1)$ \\
\hline Dekade 5 & $13(36,1)$ \\
\hline Dekade 6 & $14(38,9)$ \\
\hline Dekade 7 & $2(5,6)$ \\
\hline \multicolumn{2}{|l|}{ Tipe tumor, n (\%) } \\
\hline Tipe I & $20(55,6)$ \\
\hline Tipe II & $16(44,4)$ \\
\hline \multicolumn{2}{|l|}{ Stadium, n (\%) } \\
\hline Stadium I atau II & $19(52,8)$ \\
\hline Stadium III & $17(47,2)$ \\
\hline \multicolumn{2}{|l|}{ Ekspresi VCAM-1, n (\%) } \\
\hline Rendah & $10(27,8)$ \\
\hline Tinggi & $26(72,2)$ \\
\hline
\end{tabular}

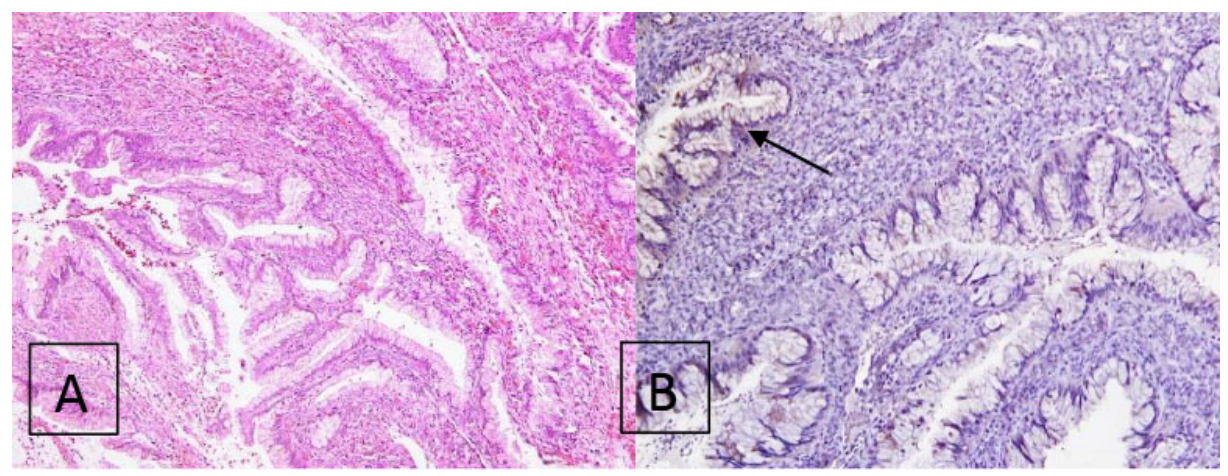

Gambar 1. Karsinoma epitel permukaan ovarium, Mucinous carcinoma menunjukkan ekspresi VCAM-1 rendah pada Tipe I (panah). A. Pulasan HE (100X). B. Pulasan IHK (100x).

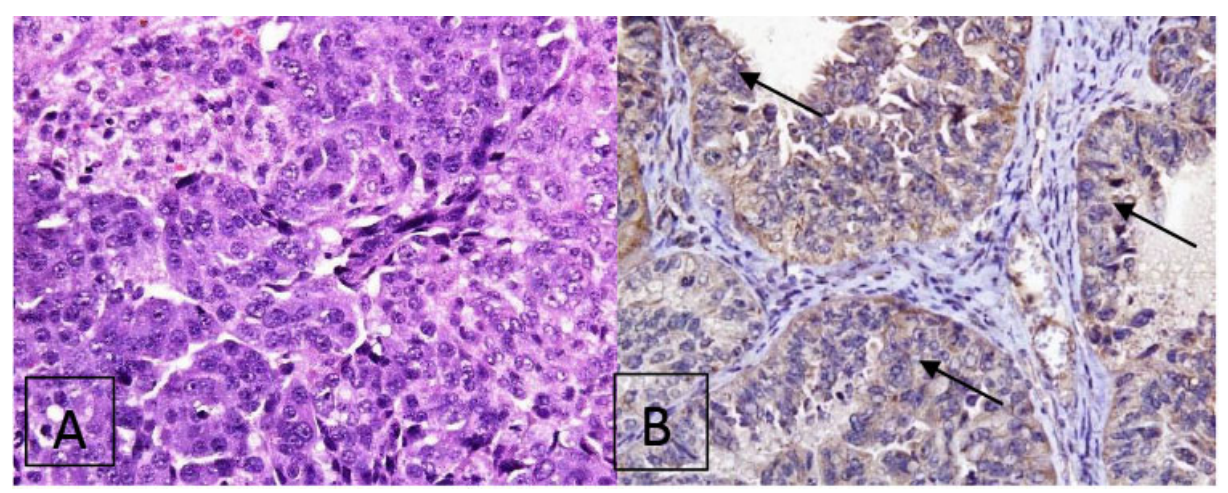

Gambar 2. Karsinoma epitel permukaan ovarium, High Grade Serous Carcinoma, tipe II, Stadium III menunjukkan ekspresi VCAM-1 tinggi (panah). A. Pulasan HE (400X). B. Pulasan IHK (400x).

$(2,8 \%)$ seromucinus carcinoma. Sedangkan karsinoma epitel permukaan ovarium tipe II terdapat 16 pasien $(44,4 \%)$ terdiri dari 5 pasien (13,9\%) endometrioid carcinoma grade III dan high grade serous carcinoma sebanyak 11 pasien $(33,3 \%)$. Berdasarkan parameter stadium $\mathrm{T}$, didapatkan hasil tumor dengan kelompok stadium I dan II sebanyak 19 pasien $(52,8 \%)$ dan kelompok stadium III sebanyak 17 pasien $(47,2 \%)$ 
Tabel 2. Distribusi ekspresi VCAM-1 berdasarkan tipe karsinoma epitel permukaan

\begin{tabular}{cccccc} 
& \multicolumn{2}{c}{ Tipe Tumor $(\mathbf{N}=\mathbf{3 6})$} & Total & PR & IK 95\% \\
\cline { 2 - 5 } Ekspresi VCAM-1 & $\mathbf{I}(\mathbf{N}=\mathbf{2 0})$ & II $(\mathbf{N}=\mathbf{1 6})$ & $10(100,0)$ & - & $1,599-4,228$ \\
\hline Rendah, $\mathrm{n}(\%)$ & $10(100,0)$ & $0(0,0)$ & & $0,001^{*}$ \\
Tinggi, $\mathrm{n}(\%)$ & $10(38,5)$ & $16(61,5)$ & $26(100,0)$ & & \\
\hline
\end{tabular}

VCAM-1: Vascular Cell Adhesion Molecule-1; PR: Prevalance Ratio; IK: Interval Kepercayaan; ${ }^{\star S e c a r a}$ statistik bermakna apabila nilai-p kurang dari 0,05 pada Fisher Exact Test

Tabel 3. Uji beda rerata ekspresi VCAM-1 berdasarkan Tipe dan Stadium Karsinoma Epitel Permukaan Ovarium dengan Independent T-Test maupun Uji Mann-Whitney.

\begin{tabular}{lccc}
\multicolumn{1}{c}{ Variabel } & Rerata \pm SB & Perbedaan Rerata & 95\% IK \\
\hline Tipe Karsinoma & & & $0,33-0,70$ \\
$\quad$ Tipe I & $1,39 \pm 0,28$ & 0,48 & $0,001^{\text {a* }}$ \\
$\quad$ Tipe II & $1,71 \pm 0,18$ & & $-0,87-6,21$ \\
Stadium & $16,00 \pm 3,42$ & 5,29 & $0,128^{\mathrm{b}}$ \\
$\quad$ Stadium I atau II & $21,29 \pm 2,76$ & & \\
$\quad$ Stadium III & & & \\
\hline
\end{tabular}

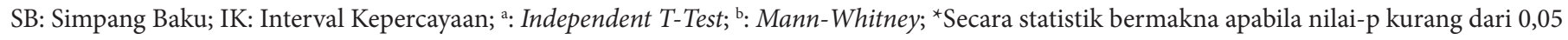

Tabel 4. Distribusi ekspresi VCAM-1 berdasarkan stadium T karsinoma epitel permukaan

\begin{tabular}{|c|c|c|c|c|c|c|}
\hline \multirow{2}{*}{ Ekspresi VCAM-1 } & \multicolumn{2}{|c|}{ Stadium $\mathrm{T}(\mathrm{N}=36)$} & \multirow{2}{*}{ Total } & \multirow{2}{*}{ PR } & \multirow{2}{*}{ IK 95\% } & \multirow{2}{*}{$\mathbf{p}$} \\
\hline & I atau II (N=19) & III $(\mathrm{N}=17)$ & & & & \\
\hline Rendah, n (\%) & $9(90,0)$ & $1(10,0)$ & $10(100 \%)$ & 2,3 & $1,380-3,969$ & 0,007 \\
\hline Tinggi, n (\%) & $10(38,5)$ & $16(61,5)$ & $25(100 \%)$ & & & \\
\hline
\end{tabular}

VCAM-1: Vascular Cell Adhesion Molecule-1; PR: Prevalance Ratio; IK: Interval Kepercayaan; ${ }^{\star}$ Secara statistik bermakna apabila nilai-p kurang dari 0,05 pada Fisher Exact Test

\section{(Tabel 1).}

Ekspresi protein VCAM-1 pada pulasan imunohistokimia dievaluasi pada sampel penelitian menggunakan metode skoring sesuai dengan definisi operasional yang telah ditetapkan sebelumnya. Pada penelitian ini, didapatkan ekspresi VCAM-1 rendah pada 10 pasien $(27,8 \%)$ dan ekspresi VCAM-1 tinggi pada 26 pasien $(72,2 \%)$ (Tabel 1). Hasil pulasan Hematoksilin-Eosin (HE) dan imunohistokimia pulasan VCAM-1 pada penelitian ini disajikan pada Gambar 1 dan 2.

Tabel 2 menunjukkan bahwa pada karsinoma epitel permukaan ovarium dengan ekspresi VCAM-1 rendah, terdapat $10(100,0 \%)$ pasien karsinoma epitel permukaan ovarium tipe I dan 0 $(0,0 \%)$ pasien merupakan karsinoma epitel permukaan ovarium tipe II. Sedangkan pada kasus dengan ekspresi VCAM1 tinggi, terdapat $10(38,5 \%)$ pasien merupakan karsinoma epitel permukaan ovarium tipe I dan $16(61,5 \%)$ pasien merupakan karsinoma epitel permukaan ovarium tipe II. Dari analisis chi-square didapatkan uji Fisher's Exact dengan nilai $\mathrm{p}=0,001$, sehingga dapat disimpulkan terdapat hubungan yang bermakna secara statistik antara ekspresi VCAM-1 dengan tipe karsinoma epitel permukaan ovarium. Analisis Prevalence Ratio (PR) tidak dapat ditampilkan karena terdapat angka nol pada hasil ekspresi VCAM-1 terhadap tipe I karsinoma epitel permukaan ovarium (Tabel 2).

Setelah itu, uji normalitas data dengan Shapiro-Wilk juga dilakukan terhadap data ekspresi VCAM-1 berdasarkan karsinoma epitel permukaan ovarium tipe I maupun tipe II karsinoma ovarium yang menunjukkan data tidak berdistribusi normal dengan nilai $\mathrm{p}<0,05$ sehingga dilanjutkan uji log persentase dengan transformasi data. Setelah data berdistribusi normal, selanjutnya dilakukan Independent T-test (Tabel 3). Berdasarkan Tabel 3 perbedaan rerata ekspresi VCAM-1 antara kelompok dengan karsinoma epitel permukaan ovarium tipe I dan tipe II menunjukkan nilai yang bermakna secara statistik dengan $\mathrm{p}=0,001$ (IK 95\%=0,33-0,70) (Tabel 3). Setelah itu, uji normalitas data dengan Shapiro-Wilk juga dilakukan terhadap data ekspresi VCAM-1 berdasarkan kelompok stadium I atau II dan kelompok stadium III karsinoma epitel permukaan ovarium yang menunjukkan data tidak berdistribusi normal dengan nilai $\mathrm{p}<0,05$ sehingga dilanjutkan dengan uji non parametrik yaitu dengan uji Mann-Whitney (Tabel 3). Berdasarkan Tabel 3 perbedaan rerata pada ekpresi VCAM-1 antara kelompok stadium I atau II dan stadium III karsinoma epitel permukaan ovarium menunjukkan tidak ada perbedaan secara statistik dengan nilai $\mathrm{p}=0,128$.

Tabel 4 menunjukkan bahwa pada karsinoma epitel permukaan ovarium dengan ekspresi VCAM-1 rendah yaitu $9(90,0 \%)$ pada pasien memiliki stadium T I atau II dan 1 (10,0\%) pada pasien memiliki stadium T III. Sedangkan pada 
kasus dengan ekspresi VCAM-1 tinggi yaitu $10(38,5 \%)$ pada pasien memiliki stadium T I atau II dan $16(61,5 \%)$ pasien memiliki stadium T III. Dari analisis chisquare didapatkan uji fisher's exact dengan nilai $\mathrm{p}=0,007$, sehingga dapat disimpulkan terdapat hubungan yang bermakna secara statistik antara ekspresi VCAM-1 dengan stadium karsinoma epitel permukaan. Analisis prevalence ratio menunjukkan hasil bahwa ekspresi VCAM-1 yang tinggi memiliki kemungkinan 2,3 kali lebih besar terjadi pada kelompok karsinoma ovarium stadium III dibandingkan dengan karsinoma ovarium stadium I dan II (interval kepercayaan 95\% = 1,3803,969) (Tabel 4).

\section{PEMBAHASAN}

Kejadian risiko kanker ovarium dilaporkan meningkat seiring dengan bertambahnya usia. Karsinoma epitel permukaan ovarium merupakan penyakit yang berhubungan dengan usia dan utamanya terjadi pada usia setelah menopause. Peningkatan insiden terlihat pada usia lebih dari 65 tahun, beberapa penelitian menyebutkan median usia penderita antara 50-79 tahun. $^{12}$ Penelitian yang dilakukan oleh Arora $\mathrm{N}$ et al., terhadap 6.975 pasien yang didiagnosis karsinoma epitel permukaan ovarium mulai tahun 1990 hingga 2014 di British, Colombia, Kanada didapatkan $4.382(68,2 \%)$ pasien berusia 50 hingga 79 tahun. ${ }^{13}$ Rentang usia terbanyak ditemukan pada usia dekade keenam (50-59 tahun) sebanyak 1.477 (23\%) pasien. ${ }^{13}$ Penelitian tersebut sesuai dengan hasil penelitian penulis yaitu didapatkan dominasi usia pada dekade keenam sebanyak 14 (38,9\%). Studi tentang hubungan usia dekade keenam (usia paska menopause) dengan terjadi karsinoma epitel ovarium masih belum jelas dan bervariasi namun berdasarkan studi oleh Momenimovahed $\mathrm{Z}$ et al., menunjukkan faktor risiko terjadinya kanker ovarium seperti faktor demografi (usia) merupakan faktor predisposisi yang kemungkinan dapat diteliti lebih lanjut, juga faktor-faktor lain seperti faktor reproduksi, hormonal maupun genetik yang kemungkinan dapat berhubungan dengan usia. ${ }^{12}$

Tipe histologi tersering dari karsinoma epitel permukaan ovarium adalah high grade serous carcinoma. ${ }^{12}$ Arora $\mathrm{N}$ et al., menyebutkan terdapat $2.996 \quad(46,6 \%)$ pasien merupakan serous carcinoma diikuti oleh endometrioid carcinoma sebanyak 719 (11,2\%) pasien. ${ }^{13}$ Penelitian lainnya yang dilakukan oleh Arania R dan Windarti I yang meneliti karakteristik pasien kanker ovarium di Rumah Sakit Dr. H. Abdul Moeloek Bandar Lampung tahun 2009-2013 mendapatkan tipe histologi tersering adalah tipe serous yaitu sebanyak $20 \%$ kasus. ${ }^{14}$ Penelitian ini mendapatkan tipe histologi yang tersering adalah high grade serous carcinoma sebanyak $11(33,3 \%)$ pasien, diikuti low grade serous carcinoma sebanyak $6(13,9 \%)$ pasien, kemudian endometrioid carcinoma grade III sebanyak 5 (13,9\%) pasien.

Ekspresi VCAM-1 pada kanker terjadi melalui aktivasi sel-sel endothelial dan mesothelial, dan mempunyai peran penting dalam onkogenesis, tumor angiogenesis, perkembangan tumor, dan metastasis kanker pada manusia. ${ }^{8}$ VCAM-1 mempunyai peran penting dalam onkogenesis, tumor angiogenesis, perkembangan tumor, dan metastasis kanker pada manusia. ${ }^{8}$ Pada kanker ovarium, Huang J et al., melaporkan bahwa sel kanker ovarium dengan overekspresi VCAM-1 (dibandingkan dengan sel kontrol) memiliki kemampuan migrasi sel yang meningkat dan merangsang pertumbuhan xenograft tumor pada tikus. Hal tersebut menunjukkan bahwa VCAM1 berperan penting pada pertumbuhan tumor ovarium. ${ }^{10}$ Penelitian ekspresi VCAM-1 pada tumor ovarium dengan jaringan normal ovarium menunjukkan bahwa ekspresi VCAM-1 terpulas positif $\geq 30 \%$ secara dominan pada sitoplasma sel-sel karsinoma dan sel stroma. ${ }^{10}$ Penelitian ini juga menganalisis hubungan antara ekspresi VCAM-1 dengan berbagai variabel klinikopatologi pasien tumor ovarium, hasilnya didapatkan ekspresi tinggi pada karsinoma epitel permukaan ovarium (40\%), serous cystadenoma (10\%), tuba falopi (0\%) dan ovarium normal (0\%), sehingga menunjukkan hasil ini berbeda secara bermakna dengan nilai $\mathrm{P}=0,02 .^{10}$

Penelitian ini menemukan hubungan yang bermakna secara statistik antara ekspresi VCAM-1 dengan tipe karsinoma epitel permukaan ovarium $(\mathrm{p}=0,001)$.
Pada karsinoma epitel permukaan ovarium dengan ekspresi VCAM-1 tinggi yaitu $61,5 \%$ pasien merupakan karsinoma epitel permukaan ovarium tipe II yang bersifat lebih agresif. Hasil uji beda rerata ekspresi VCAM-1 pada karsinoma epitel permukaan ovarium sebesar 0,48 dengan nilai $\mathrm{p}=0,001$ (IK 95\%=0,33-0,70) yang berbeda bermakna secara statistik. Hasil ini dapat menjelaskan bahwa ekspresi VCAM-1 yang tinggi pada karsinoma epitel permukaan ovarium tipe II dibandingkan tipe I karena VCAM-1 berperanan penting dalam pertumbuhan dan penyebaran sel kanker dengan cara menstimulasi sel-sel kanker bermigrasi menuju kavum peritoneum. ${ }^{9}$ Studi ini juga sejalan dengan karakteristik karsinoma ovarium tipe II yang memiliki sifat lebih agresif dibanding tipe I dan secara molekuler kemungkinan juga terjadi mutasi p53 yang merupakan goodmarker dalam menilai potensi metastasis. ${ }^{15,16}$

Penelitian tentang hubungan antara ekspresi VCAM-1 sebagai penanda karsinoma serus terhadap kemampuan invasif dan resistensi kemoterapi pada kanker ovarium, menunjukkan bahwa protein tersebut terekspresi tinggi pada sel-sel kanker yang resisten terhadap PTX, pada kemoresisten serta pada kanker epitel ovarium yang poorly differentiated maupun stadium lanjut. Hal ini dikaitkan dengan peningkatan kemampuan invasif. Data ini menunjukkan bahwa paparan PTX dosis tinggi meningkatkan sifat karsinoma serous ovarium (yaitu overexpression VCAM-1, yang mengarah pada pengembangan resistensi Paclitaxel (PTX), peningkatan invasi dan metastasis yang jauh, dan prognosis buruk pada kanker ovarium. ${ }^{17}$

Hasil studi yang ditunjukkan Huang J et al., secara statistik tidak menunjukkan hubungan yang bermakna terhadap stadium, namun studi lain menunjukkan hubungan antara ekspresi VCAM-1 dengan stadium karsinoma ovarium yang bermakna secara statistik. ${ }^{10} \mathrm{Hal}$ ini sesuai dengan hasil dari penelitian ini dimana ditemukan adanya hubungan yang bermakna secara statistik antara ekspresi VCAM-1 dengan stadium karsinoma epitel permukaan $(\mathrm{p}=0,007)$. Overekspresi VCAM lebih banyak ditemukan pada pasien stadium T III. Selain itu ditemukan 
bahwa ekspresi VCAM-1 yang tinggi memiliki kemungkinan 2,3 kali lebih besar untuk menjadi karsinoma epitel permukaan ovarium stadium III dibandingkan dengan stadium I atau II (IK 95\%=1,380-3,969).

\section{SIMPULAN}

Terdapat hubungan antara ekspresi VCAM-1 tinggi dengan tipe karsinoma epitel permukaan ovarium dan stadium $\mathrm{T}$ dengan kemungkinan 2,3 kali terjadi pada kelompok stadium III dibandingkan stadium I atau II.

\section{KONFLIK KEPENTINGAN}

Penulis menyatakan tidak terdapat konflik kepentingan terkait publikasi dari penelitian ini.

\section{ETIKA PENELITIAN}

Penelitian ini telah mendapatkan persetujuan dari Komite Etik Fakultas Kedokteran Universitas Udayana/RSUP Sanglah Denpasar dengan No. 2371/UN 14.2.2.VII.14/LT/2020.

\section{PENDANAAN}

Penelitian ini tidak mendapatkan bantuan dana hibah dari pemerintah maupun sektor swasta lainnya.

\section{KONTRIBUSI PENULIS}

Seluruh penulis memiliki kontribusi yang sama dalam penulisan laporan penelitian ini baik dari tahap penyusunan kerangka konsep, pengumpulan data, analisis data, hingga interpretasi hasil penelitian dalam bentuk publikasi ilmiah.

\section{DAFTAR PUSTAKA}

1. Cohen M, Petignat P. Purified autoantibodies against glucose-regulated protein 78 (GRP78) promote apoptosis and decrease invasiveness of ovarian cancer cells. Cancer Lett. 2011;309(1):104-109.

2. Siegel RL, Miller KD, Jemal A. Cancer statistics, 2019. CA Cancer J Clin. 2019;69(1):7-34.

3. Reid BM, Permuth JB, Sellers TA. Epidemiology of ovarian cancer: a review. Cancer Biol Med. 2017;14(1):9-32.

4. Sari NNS, Suryantari SAA, Darmawan IPGP, Satyarsa ABS, Budiana ING. General Profile of Ovarian Cancer Patients in Sanglah General Hospital, Bali from January 2016 to December 2017. Int J Gynecol Cancer. 2018;28:836-836.

5. La Vecchia C. Ovarian cancer: epidemiology and risk factors. Eur J Cancer Prev. 2017;26(1):5562.

6. Prat J. Ovarian carcinomas: five distinct diseases with different origins, genetic alterations, and clinicopathological features. Virchows Arch. 2012;460(3):237-249.

7. Hsieh SF, Lau HY, Wu HH, Hsu HC, Twu NF, Cheng WF. Prognostic Factors of Early Stage Epithelial Ovarian Carcinoma. Int J Environ Res Public Health. 2019;16(4):637.

8. Yurkovetsky Z, Skates S, Lomakin A, Nolen B, Pulsipher T, Modugno F, et al. Development of a multimarker assay for early detection of ovarian cancer. J Clin Oncol. 2010;28(13):2159-66.

9. Arjmand M, Avval FZ. Clinical Biomarkers for Detection of Ovarian Cancer. J Mol Cancer. 2019;2(1):3-7.

10. Huang J, Zhang J, Li H, Lu Z, Shan W, MercadoUribe I, et al. VCAM1 expression correlated with tumorigenesis and poor prognosis in high grade serous ovarian cancer. Am J Transl Res. 2013;5(3):336-46.

11. Scalici JM, Thomas S, Harrer C, Raines TA, Curran J, Atkins KA, et al. Imaging VCAM-1 as an indicator of treatment efficacy in metastatic ovarian cancer. J Nucl Med. 2013;54(11):18839.

12. Momenimovahed Z, Tiznobaik A, Taheri S, Salehiniya H. Ovarian cancer in the world: epidemiology and risk factors. Int J Womens Health. 2019;11:287-299.

13. Arora N, Talhouk A, McAlpine JN, Law MR, Hanley GE. Long-term mortality among women with epithelial ovarian cancer: a population-based study in British Columbia, Canada. BMC Cancer. 2018;18(1):1039.

14. Arania R, Windarti I. Karakteristik Pasien Kanker Ovarium di Rumah Sakit Dr. H. Abdul Moelok Bandar Lampung Tahun 2009-2013. Juke Unila. 2015;5(9):43-47.

15. Kurman RJ, Shih IeM. The Dualistic Model of Ovarian Carcinogenesis: Revisited, Revised, and Expanded. Am J Pathol. 2016;186(4):733747.

16. Prabawa IPY, Bhargah A, Liwang F, Tandio DA, Tandio AL, Lestari AAW, et al. Pretreatment Neutrophil-to-Lymphocyte ratio (NLR) and Platelet-to-Lymphocyte Ratio (PLR) as a Predictive Value of Hematological Markers in Cervical Cancer. Asian Pac J Cancer Prev. 2019 Mar 26;20(3):863-868.

17. Zhang J, Yuan B, Zhang H, Li H. Human epithelial ovarian cancer cells expressing CD105, CD44 and CD106 surface markers exhibit increased invasive capacity and drug resistance. Oncol Lett. 2019;17(6):5351-5360.

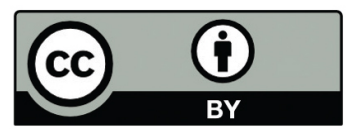

This work is licensed under a Creative Commons Attribution 